\title{
ANATOMICAL AND MOLECULAR RESPONSES OF SOY BEAN (Glycine max (L.) Merr.) DUE TO SALINITY STRESSES
}

\section{RESPON ANATOMI DAN MOLEKULER TANAMAN KEDELAI (Glycine max (L.) Merr.) AKIBAT STRESS GARAM}

\author{
Juwarno $^{1 *}$, Siti Samiyarsih ${ }^{1}$ \\ ${ }^{1}$ Faculty of Biology, Universitas Jenderal Soedirman, Purwokerto, Indonesia. \\ *email : juwarno51@yahoo.com
}

Received October 27, 2016; Accepted May 9, 2017; Available online May 30, 2017

\begin{abstract}
The Current study was aimed to explore both anatomical and molecular responses of 3 soy bean cultivars (Mahameru, Slamet, and Dam) which caused by salt stress. The result showed that Mahameru cultivar has the widest stomata on upper epiderm $11.38 \mu \mathrm{m}$, the thickest upper epiderm was $10.71 \mu \mathrm{m}$, the thickest of lower epiderm was $9.98 \mu \mathrm{m}$, the highest density of stomata on lower epiderm was 13.66 per $\mathrm{mm}^{2}$ leaf area, and the thickest mesophylll was $110.37 \mu \mathrm{m}$. The application of OPA-4 primer with RAPD technique showed there were not genetically different on Mahameru cultivar between control and treatment $80 \mathrm{mM}$ $\mathrm{NaCl}$. The OPA-8 primer showed that the control block of Slamet cultivar was different from either control block of others as well as treatment block of $80 \mathrm{mM} \mathrm{NaCl}$. The use of OPA-18 primer showed that the Slamet cultivar of the control block and so its $80 \mathrm{mM} \mathrm{NaCl}$ block was different from Dam and Mahameru, where the 500th base of Slamet cultivar did not have DNA band.
\end{abstract}

Key words: anatomical responses, epiderm, mesophylll, soy bean, salt stress

\begin{abstract}
ABSTRAK
Tujuan dari penelitian ini adalah untuk mengetahui respon anatomi dan molekuler tiga kultivar kedelai (Mahameru, Slamet dan Detam)akibat stress garam. Hasil penelitian menunjukkan bahwa stomata epidermis atas paling lebar $11,38 \mu \mathrm{m}$, epidermis atas paling tebal $10,71 \mu \mathrm{m}$, epidermis bawah paling tebal $9,98 \mu \mathrm{m}$, stomata epidermis bawah paling rapat 13,66 per $\mathrm{mm}^{2}$ luas daun, dan mesofil paling tebal $110,37 \mu \mathrm{m}$ semua parameter tersebut dimiliki oleh kultivar Mahameru. Hasil analisis molekuler dengan primer RAPD OPA-2 menunjukkan bahwa kultivar Detam dan Slamet berbeda satu sama lain dan keduanya berbeda dengan kultivar Mahameru. Penggunaan primer RAPD OPA-4 menunjukkan tidak ada perbedaan genetik antara perlakuan kontrol dengan perlakuan $80 \mathrm{mM} \mathrm{NaCl}$ pada kultivar Mahameru. Penggunaan primer RAPD OPA-8 menunjukkan bahwa genetik Slamet kontrol berbeda dengan perlakuan kontrol dan $80 \mathrm{mM} \mathrm{NaCl}$ lainnya. Penggunaan primer RAPD OPA-18 menunjukkan bahwa genotipe Slamet baik kontrol maupun perlakuan $80 \mathrm{mM} \mathrm{NaCl}$ berbeda dengan genotipe Detam dan Mahameru. Perbedaan terletak pada pasangan basa ke500 pada kultivar Slamet tidak memiliki pita DNA.
\end{abstract}

Kata kunci : respon anatomi, epidermis, mesofil, kedelai , stress garam

\section{INTRODUCTION}

Soy bean (Glycine max (L.) Merr.) is one among those staple foods characterized by high protein and oil. Its protein has is the important source for dietary protein. The oil produced from soy bean is highly digestible and contain no cholesterol (Kazem \& Minoo, 2011). According to (Dolatabadian, Modarressanavy \& Ganati, 2011) soy bean is one of the Fabaceae family which takes significant role in providing protein and so plant's oil. However, national production could not fulfill the domestic consumptions due to many of fertile soil areas were changed to others and left the marginal lands for agriculture
(Triyani, Suwarto \& Siti, 2013). Abiotic stress such as salinity, toxic chemicals, drought and oxidative stress are reduce plant growth and development in turn to reduce agricultural production. Toxic chemical caused by the high accumulation of toxic salt $\left(\mathrm{Na}^{+}\right.$and $\left.\mathrm{Cl}^{-}\right)$ in the leaf apoplast leads to dehydration and turgor loss, eventually death of leaf cells and tissues (Khalid et al., 2010).

Drought stress when water supply to the root become limited and the transpiration become very high. Drought stress affects water status in plant and decreased the chlorophyll content (Makbul, Guler, Durmus \& Guven, 2011). Salt stress has been destructed effect on cultivated land in result it 
cause a $30 \%$ of loss production (Zahra \& Kandi, 2011). In Indonesia, saline soil belongs to the marginal area (Yuniati, 2004). Excess amount of Salt in the soil adversely affects the plant growth and development lead to gradual soil salinization (Kondetti, Jawali, Afte, \& Shitole, 2012).

The saline soil does not fit to plant's growth and development, including soy bean because the plant cells will accumulate $\mathrm{Na}+$ and $\mathrm{Cl}-$ leads to disruption of cell metabolisms. Also saline condition might cause partial dehydration due to lost of turgor as a result the reduction in water potential. Another effect a saline condition will affect nitrogen assimilation leads to disruption in nitrate absorption $\left(\mathrm{NO}_{3}^{-}\right)$which is an important role for plant growth (Yuniati, 2004). Salt stress causes the accumulating reactive oxygen species (ROS) in the cell can damage the membrane and membrane possess of lipid, protein and nucleic acid (Baniaghil, Arzanesh, Gorbanli \& Shahbazi, 2013).

In this study was to explore anatomical and molecular characters of three soy bean cultivars which grow in the salt soil. A healthy plant characterized with thick culticles, thick epiderm, thick mesophylll, and stomata density (Dickison, 2000). An Understanding genetic variation would be highly important information in preserving and utilizing germ plasms. An RAPD (Random Amplified Polymorphic DNA) technique has been known for a long time as a proper tool for studying genetic variations of plant and so animals (Suryanto, 2002). Hussien, Habeballa, Elhadi\& Khalafalla (2011) stated the 20 cultivars of Acacia senegal was RAPD analyzed showed the genetic variation of DNA. All of A. Senegal cultivars descending of the germination with salinity concentration increased. The difference of the genetic variation leads to the varies response of the soy bean cultivar (Kondetti, Jawali, Afte \& Shitole, 2012).

\section{MATERIALS AND METHODS}

Three soy bean cultivars namely Mahameru, Slamet, and Dam were chosen as the main research's subjects. Some chemicals like ethanol, xylol, alcohol 96\%, paraffin, glacial acetic acid, formalin, glicerin, safranin in $70 \%$ alcohol, aqua dest and Stellan used for anatomical analysis. Meanwhile, molecular data obtained with the help of ethanol $96 \%$, Gene JETTA Plant Genomic DNA Purification Kit RNase, washing buffer. The following 12 RAPD primers see Table 1.

The primers were from Center for Tropical Horticulture Studies IPB, Bogor, West Java Indonesia. The primer is a common use for soy bean RAPD analyze. The research applied was a Split Plot Design . The soil used was inceptisol type. Salinity and cultivar treated as factors, salinity had five levels ( 0 $\mathrm{mM} \mathrm{NaCl}$ as control, $20 \mathrm{mM}, 40 \mathrm{mM}, 60$, and $80 \mathrm{mM} \mathrm{NaCl}$ ) and treated main plots. Three cultivars Slamet, Dam, and Mahameru were the sub plots.

Treatment given before the seed planting with poured to a polybag. Per polybag was filled with $5 \mathrm{Kg}$ sterile-soil. Soy bean was grown one seed per a polybag with size $35 \times 40 \mathrm{~cm}$. The plant care with watering two days once with streriled water.

Table 1. Primer Random Amplified Polymorphism DNA (RAPD) was used in molecular research.

\begin{tabular}{lllc}
\hline No & Primer & Sequence 5' $-3^{\prime}$ & Annealing $\left({ }^{\circ} \mathrm{C}\right)$ \\
\hline 1 & OPA-1 & CAG GCC CTT C & 36 \\
2 & OPA-2 & TGC CGA GCT G & 36 \\
3 & OPA-3 & AGT CAG CCA C & 36 \\
4 & OPA-4 & AAT CGG GCT G & 36 \\
5 & OPA-7 & GAA ACG GGT G & 36 \\
6 & OPA-8 & GTG ACG TAG G & 36 \\
7 & OPA-9 & GGG TAA CGC C & 36 \\
8 & OPA-11 & CAA TCG CCG T & 36 \\
9 & OPA-13 & CAG CAC CCA C & 36 \\
10 & OPA-17 & GAC CGC TTG T & 36 \\
11 & OPA-18 & AGG TGA CCG T & 36 \\
12 & OPA-19 & CAA ACG TCG G & 36 \\
\hline
\end{tabular}


The observation has conducted after the age 45 days after planting. For Anatomical characters analyzed according to a paraffin method of Sass (1958). The step for DNA, first the DNA scanning, first the DNA isolated from the soy bean leaf. The second the DNA resulted amplified with PCR (polymerase Chain Reaction) technique with volume total was $10 \mu \mathrm{L}$, and the third DNA product from PCR was visualised with electhroforesis technique and photographed. All steps according Doyle and Doyle, 1990. Anatomical parameters were the stomata length size of both lower and upper epiderm, the stomata width size of lower and upper epiderm, the thickness epiderm, stomata densities of upper and lower epiderm, and thickness of the mesophylll. All of the parameters was measured with light microscope $\mathrm{CH} 20$ with the occuler micrometer inside of 400x magnified. Molecular data were obtained from the presence and absence of DNA fragments in the locus.

\section{RESULTS AND DISCUSSIONS}

The result of the research the stomata length of upper and lower epiderm, stomata width of upper and lower epiderm, epiderm thickness of upper and lower, stomata density of upper and lower epiderm, and mesophylll thickness (Table 2). The upper and lower stomata length not significant among soy bean cultivars ( $\mathrm{p}$ < 0.05). According Makbul et al., (2011) soy bean plants which were cultivated under salt stress of their upper and lower epiderm had shorter stomata than those of plants grown in fertile soil. Reduction in stomata's length is mainly due to the presence of $\mathrm{Na}^{+}$and $\mathrm{Cl}^{-}$which disturb absorption of water molecule from the medium lead to disrupt its balance between $\mathrm{Ca}^{2+}$ and $\mathrm{K}^{+}$and further reduction on osmotic potential in the cell. The upper stomata width was significant among three soy bean cultivars ( $p>0.05$ ). The widest upper stomata was Mahameru cultivar. The lower stomata width not significant among soy bean cultivars ( $\mathrm{p}<$ 0.05). The stomata width both upper and lower epiderm of the soy bean plants in salt stress was reduced.

Reduction was mainly caused by reducing osmotic potential and disrupting the root to take water molecule from the soil (Makbul et al., 2011). The two aspects also reduce cell's size (Atabayeva et al., 2013). Salt stress has been associated to imbalance in ionic and nutrient status of plant and overproduction of reactive oxygen species (ROS). The consequence of ROS produced in chloroplast, mitochondria and peroxisomes is damage to lipids, protein and nucleic acid in turn reduce plant growth (Nafees et al., 2014).

The thickness of the upper and lower epiderm was strongly affected by cultivar difference. The thickest upper epiderm of $10.71 \mu \mathrm{m} \quad(\mathrm{P} \geq 0,01)$ was shown by the Mahameru cultivar. The upper and lower epiderm thickness was significant among the soy bean cultivars $(\mathrm{p}>0.01)$. The thickest lower epiderm was $9.98 \mu \mathrm{m}$ from Mahameru cultivar. Epiderm cells thickness of upper leaf epiderm was reduced by salt stress (Mansoor et al., 2013).

Table 2. The average stomata length upper and lower, stomata width, epiderm thickness, stomata density, and mesophylll thickness.

\begin{tabular}{|c|c|c|c|c|}
\hline & \multicolumn{3}{|c|}{ Cultivar } & \multirow[b]{2}{*}{$\begin{array}{c}\text { Significance } \\
\text { Level }\end{array}$} \\
\hline & $\begin{array}{c}\mathrm{S} \\
\text { (Slamet) }\end{array}$ & $\begin{array}{c}\mathrm{D} \\
(\mathrm{Dam})\end{array}$ & $\begin{array}{c}\mathrm{M} \\
\text { (Mahameru) }\end{array}$ & \\
\hline Upper Stomata Length $(\mu \mathrm{m})$ & $18.82 \pm 1.29$ & $18.66 \pm 1.29$ & $19.75 \pm 2.18$ & $\mathrm{P}<0.05$ \\
\hline Stomata Length $(\mu \mathrm{m})$ & $18.54 \pm 1.19$ & $18.15 \pm 1.30$ & $18,49 \pm 1.89$ & $\mathrm{P}<0.05$ \\
\hline Upper Stomata Width $(\mu \mathrm{m})$ & $11.32 \pm 1.12$ & $10.49 \pm 1.16$ & $11.38 \pm 1.02$ & $\mathrm{P}>0.05$ \\
\hline Stomata Width $(\mu \mathrm{m})$ & $10.96 \pm 1.18$ & $10.66 \pm 1.14$ & $11.43 \pm 0.86$ & $\mathrm{P}<0.05$ \\
\hline Upper Epiderm Thickness $(\mu \mathrm{m})$ & $8.93 \pm 0.96$ & $9.59 \pm 1.29$ & $10.71 \pm 0.82$ & $\mathrm{P}>0.01$ \\
\hline Epiderm Thickness $(\mu \mathrm{m})$ & $8.21 \pm 1.03$ & $9.48 \pm 1.29$ & $9.98 \pm 1.37$ & $\mathrm{P}>0.01$ \\
\hline Upper Stomata Density per $\mathrm{mm}^{2}$ & $4.93 \pm 1.05$ & $5.17 \pm 1.48$ & $4.72 \pm 0.80$ & $\mathrm{P}<0.05$ \\
\hline Stomata Density per $\mathrm{mm}^{2}$ & $11.68 \pm 2.27$ & $11.50 \pm 2.34$ & $13.66 \pm 2.39$ & $\mathrm{P}>0.05$ \\
\hline Mesophylll Thickness $\mu \mathrm{m}$ & $91.82 \pm 13.69$ & $95.87 \pm 10.24$ & $110.37 \pm 18.09$ & $P>0.01$ \\
\hline
\end{tabular}


Salt stress lowers water potential it prevent water uptake by plant. It caused to reduce water absorption by root resulting in "physiological drought" (Arshi et al., 2010). Epiderm is the protecting tissue for the plants from injury, water loss by evaporate, and for deposit water. Such plants grow in the dessert for examples have more than one layer epiderm (Dickison, 2000; Cutler et al., 2011). Rafi et al., (2013) stated plants tolerant to the salt stress affected by three physiological processes : osmotic pressure regulation, cell division and plant growth regulation, and detoxification of poisonous matter in the cellular level. Accumulations of $\mathrm{Na}^{+}$and $\mathrm{Cl}^{-}$ which is known as toxic compound to the plant (Kondetti et al., 2012). Salt stress inhibit cell division and the cell cycle, as well as cell elongation. Similar changes in leaf anatomy such as the number and size stomata (Biljana et al., 2013). According Atabayeva et al., (2013) salt stress reduced the growth and biomass of plant, reduce the thickness of the upper and the lower epiderm. Reduced plant develovment in salt stress can be consequence of either the direct toxic effect of salts or the general delay in the germination process caused by osmotic stress (Kondetti et al., 2012). Due to the toxic effects of salt and restrict water uptake and root growth in turn they caused the whole soy bean plant growth and development (Zahra and Mehdi, 2011; ElRodeny and El-Okkiah, 2012).

Cultivars treatment significantly different of the stomata density of lower epiderm $(\mathrm{P}>0.05)$. The densest stomata noted from Mahameru cultivar of 13.66 per $\mathrm{mm}^{2}$ leaf area. The good anatomical character of a plant charaterized by many stomata with small size since these two characters may help the plant to absorb more carbon dioxide for photosynthesis and protect the plant from pathogen invasion (Fahn, 1991). According to Charles et al., (2012) lost of water in an individual plant can be limited by stomata, they can do both reduce evaporation rate and controlling water flows. When the plants face a massive dehydration, the plants are dying (Cutler, 2011). Salt tolerant plants are capable of minimizing detrimental effects of salt stress by producing a series of anatomical, morphological and physiological adaptations. Murat et al., (2011) stated that salt stress decreased the stomata density both of upper and lower epiderm. Density stomata decrease caused with osmotic effect of $\mathrm{Na}^{+}$and $\mathrm{Cl}^{-}$ ions. The ions caused by disturbance equilibrium the other ion $\left(\mathrm{K}^{+}\right.$and $\left.\mathrm{Ca}^{2+}\right)$ which in turn the $\mathrm{Na} / \mathrm{K}$ and $\mathrm{Na} / \mathrm{Ca}$ ratio were high.

Salinity did not significantly affect the thickness of mesophylll of all cultivars. However, the mesophylll thickness was significantly different $(\mathrm{P} \geq 0.01)$ when cultivar was solely observed. The thickest mesophyll $110.37 \mu \mathrm{m}$ (Figure 1) was noted from Mahameru cultivar. The thick mesophyll may affect plant's physiological processes like photosynthesis as stated by Fahn (1991) the thickest the plant's mesophyll the more photosynthesis would be. Because the mesophylll contains chloroplast which consist of chlorophyll in its palisade and spons tissues. Mesophylll consists of parenchyme cells with a thin walls contain chloroplast (Cutler at al., 2011). Charles et al., (2012) stated that mesophylll is a photosynthetic tissue consists of palisade and spons tissues contaning many chloroplasts.

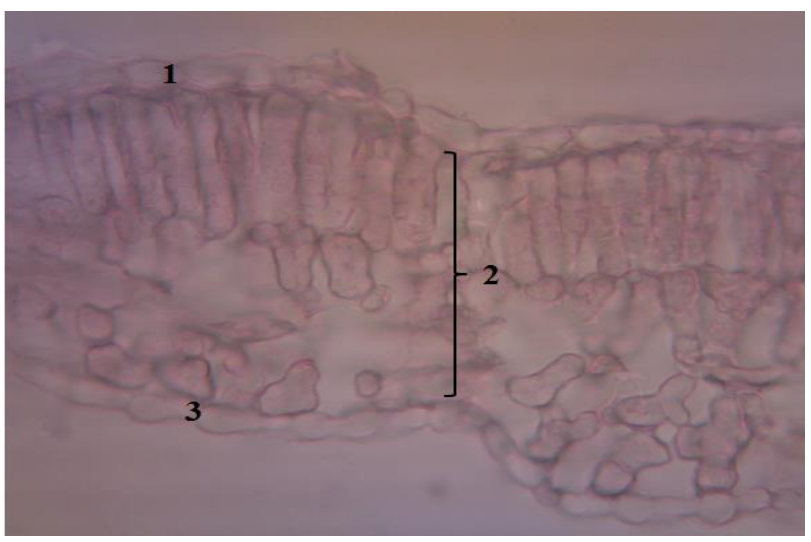

Figure 1. Cross section of Mahameru cultivar leaf (400x) as anatomical responses of soy bean (Glycine $\max$ (L.) Merr.) due to salt stress. 1. Upper epiderm, 2. Mesophylll, and 3. Lower epiderm. 


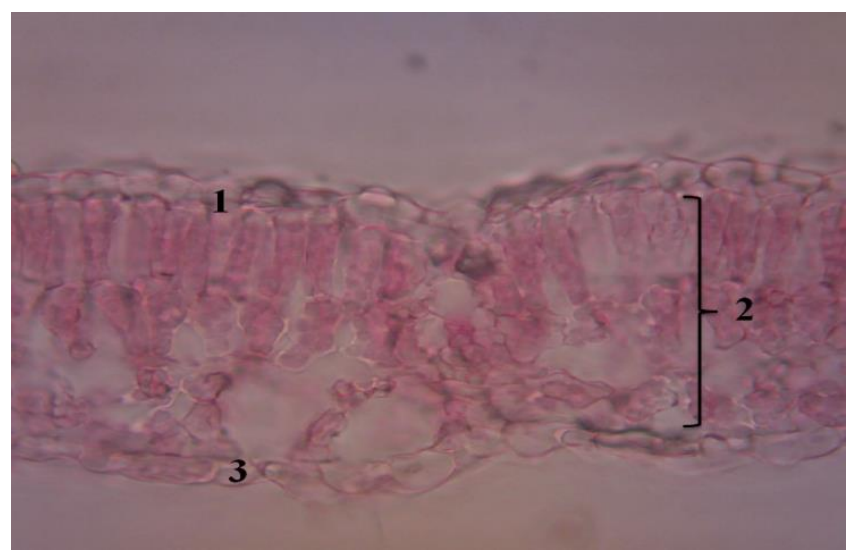

Figure 2. Cross section of Slamet cultivar leaf (400x) as anatomical responses of soy bean (Glycine $\max$ (L.) Merr.) due to salt stress. 1. Upper epiderm, 2. Mesophylll, and 3. Lower epiderm.

Current study noted that the thinnest mesophylll of $91.82 \mu \mathrm{m}$ (Figure 2) observed from Slamet cultivar. The leaves mesophylll of plants grown in high salinity were thicker than those of plants grown in low salinity. The mesophylll thickness increased with increase of salinity level. Moreover the salinity stress do not only affected on leaves but also to stem and root of soy bean plants (El-Rodeny et al., 2012). Khalid et al., (2010) stated that soil salinity affects various physiological and biochemical processes which result in reduced plants growth at almost all growth stages including germination, seedling, vegetative and maturity stages. Plants growth through salt stress might be reduced and decreased by osmotic stress and water potential in root growth environment (Sopalian et al., 2013).

Molecular analysis was carried out in Center for Tropical Horticulture Studies IPB, Bogor, on July 2015. Applying RAPD primers of OPA-2, OPA-4, OPA-8, and OPA-18 showed there were genetical differences among those three cultivars (Slamet, Dam and Mahameru), but other primers did not show differences between the soybean plant. The RAPD primer of OPA-2 showed cultivar Slamet of control plot was different from 80 $\mathrm{mM} \mathrm{NaCl}$ plot and so between Dam cultivar of control and $80 \mathrm{mM} \mathrm{NaCl}$ on DNA fragment at 500, 1000 and 1500 base pairs (Figure 3). Application of OPA-4 RAPD primer showed if control plot of Slamet cultivar was different from $80 \mathrm{mM} \mathrm{NaCl}$ plot on DNA fragment at 1500 base pairs. The Dam and Mahameru cultivars have similar genetic characters (Figure 3). On the application of OPA-8 RAPD primer at the 750 base pairs that Slamet did not amplify DNA band (Figure 4). This case showed that the DNA at 750 base pairs have not DNA band. Brown et al., (2009) stated that RAPD technique as one alternative for identification plant genetic diversity. The OPA-18 RAPD primer at control plot of Slamet cultivar as well as 80 $\mathrm{mM} \mathrm{NaCl}$ plot did not show DNA bands at 500 base pairs (Figure 5). In this case showed the DNA bands at 500 base pairs of Slamet cultivar was polymorphic differ with two other cultivar Dam and Mahameru. This analysis without using negative and positive control. On the RAPD markers, alleles have variation obvious if there is polymorphisms of the DNA bands.

According to (Hardys, 1992) analysis of molecular markers by application of RAPD primers will amplify some genetic segments with polymorphisms, and some others are monomorphisms either within or between population. Sukmarani (2013) stated that the utilizing genetic signed RAPD for observation genetic variation of mangrove plants at three locations (Segara Anakan Bay, Baluran National Park, and Karimunjawa National Park) was success. The higher genetic variation were belonged by Segara Anakan Bay mangrove, followed by Baluran National Park and Karimunjawa National Park mangrove. 


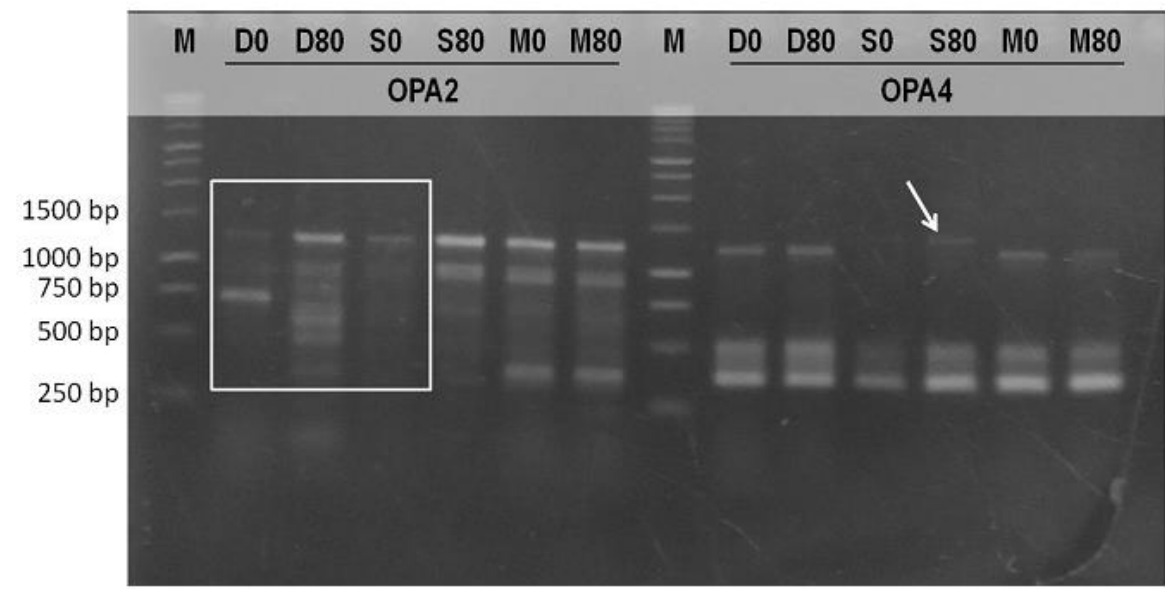

Figure 3. Visualization of DNA fragments according to PCR with OPA2 and OPA4 RAPD primers. M= Marker; DO : Dam $0 \mathrm{mM} \mathrm{NaCl}$; D80 : Dam $80 \mathrm{mM} \mathrm{NaCl}$; S0 : Slamet $0 \mathrm{mM}$ $\mathrm{NaCl}$; S80 : Slamet $80 \mathrm{mM} \mathrm{NaCl}$; M0 : Mahameru $0 \mathrm{mM} \mathrm{NaCl}$; M80 : Mahameru $80 \mathrm{mM}$ $\mathrm{NaCl}$. Square showed the polymorphic DNA with OPA2 RAPD primer among D0, D80, and S0. Arrow showed that S0 and S80 were polymorphic DNA with OPA4 RAPD primer among D0, D80, M0, and M80.

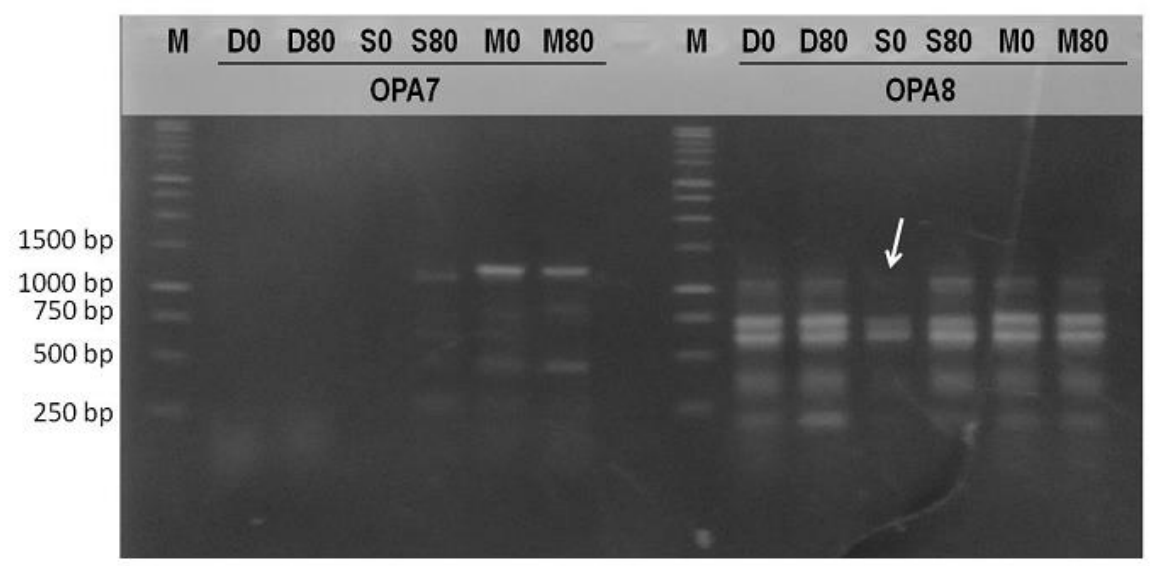

Figure 4. Visualization of DNA fragments according to PCR with OPA7 and OPA8 RAPD primers. M= Marker; DO : Dam $0 \mathrm{mM} \mathrm{NaCl}$; D80 : Dam $80 \mathrm{mM} \mathrm{NaCl}$; S0 : Slamet $0 \mathrm{mM}$ $\mathrm{NaCl}$; S80 : Slamet $80 \mathrm{mM} \mathrm{NaCl}$; M0 : Mahameru $0 \mathrm{mM} \mathrm{NaCl}$; M80 : Mahameru $80 \mathrm{mM}$ $\mathrm{NaCl}$. Arrow showed that $\mathrm{S} 0$ was polymorphic DNA at 1000 base pairs with OPA8 RAPD primer.

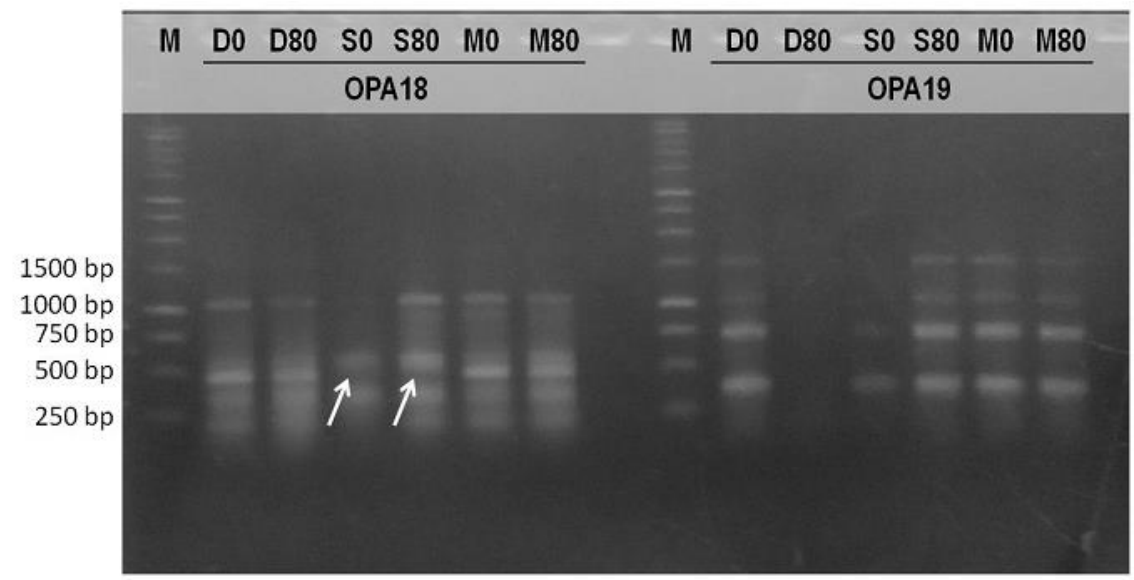

Figure 5. Visualization of DNA fragments according to PCR with OPA-18 RAPD primers. $\mathrm{M}=$ Marker; DO : Dam $0 \mathrm{mM} \mathrm{NaCl}$; D80 : Dam $80 \mathrm{mM} \mathrm{NaCl}$; S0 : Slamet $0 \mathrm{mM} \mathrm{NaCl}$; S80 : Slamet $80 \mathrm{mM} \mathrm{NaCl}$; M0 : Mahameru $0 \mathrm{mM} \mathrm{NaCl}$; M80 : Mahameru $80 \mathrm{mM} \mathrm{NaCl}$. Arrow showed that the S0 and $\mathrm{S} 80$ at 500 base pairs have not DNA band. 


\section{CONCLUSION}

The current study of anatomical and molecular responses of soy bean due to saline stresses it might be concluded, the upper stomata length, lower stomata length, lower stomata width, and upper stomata density were not affected by salt stress treatments. While the upper stomata width, lower stomata density, upper epiderm thickness, lower epiderm thickness, and the mesophylll thickness was affected by salt stress treatment. Mahameru cultivar differs from two other cultivars in the widest upper stomata, the thickest upper epiderm, the thick lower epiderm, the densest upper stomata, and the thickest mesophylll. Molecular analysis by applying RAPD primer of OPA-18 showed the Mahameru cultivar has different genetic character from Slamet and Dam. Based anatomical characters and DNA characters Mahameru cultivar considered as the soy bean tolerant to salt stress. Future research would the higher salt concentration used the Mahameru cultivar to observe anatomical, physiological, and production aspects.

\section{ACKNOWLEDGEMENT}

We would like to express our gratitude thank to the Ministry of Research, Technology, and Higher Education of the Republic of Indonesia for funding this research through Hibah Bersaing scheme No. DIPA-023.04.1.673453/2015.

\section{REFERENCES}

Arshi, A., Ahmad, A., Aref, I.M., Iqbal, M. 2010. Calcium interaction with salinity induced a growth of soy bean (Glycine $\max$ L.) cultivar. Journal of Environmental Biology. Triveni Enterprises, India. Vol 35 (1).

Atabayeva, S., Nurmahanova, a., Minocha, S., Ahmetova, A., Kenzebayeve, S., Aidosova, S., Nurzhanova, A., Zhardamalieva, A., Asrandina, S., Alybayeva, R., \& Tamara, Li. (2013). The effect of salinity on growth and anatomical attribute of barley seedling (Hordeum vulgare L.). Academic of Journal of Biotechnology. 12 (pp. 23662377).

Baniaghil, N., Arzanesh, M.H., Gorbanli, M., \& Shahbazi, M. (2013). The effect of plant growth promoting parameters, antioxidant enzymes and microelement of Canola under salt stress. Journal of applied environmental and biological sciences. (pp. 17-27). www.textroad.com.

Biljana, K., Molina, F., Janjic, N., Borja, m., Jovanovic, L.J., and Jovanovic, S.V. 2013. Effect of mixed saline and alkaline stress on the morphology and anatomy of Pisum sativum L.: the role of Peroxidase and Ascorbate Oxidase in growth regulation. Arc. Biol. Sci., Belgrade. Vol. 65 (1) : 265 - 268.

Brown, N., Venkatasamy, S., Khittoo, G., Bahorun, T., and Jawaheer, S. 2009. Evaluation of genetic diversity among 27 banana cultivars (Musa spp.) in Mauritius using RAPD markers. African Journal of Biotechnology. Vol. 8 (9) : $1834-1840$.

Charles, B.B. (2012). An introduction to plant structure and development. Plant anatomy for the twenty-first century. Cambridge University Press. Cambridge, New York.

Cutler, D.F., Ted, B. \& D.W. Stevenson, D.W. (2011). Plant anatomy and applied approach. Blackwell Publishing, USA.

Dickison, W.C. (2000). Integrative Plant anatomy. Harcourt Academic Press. New York.

Dolatabadian, A., Modarressanavy, S.A.M., \& Ganati, F. (2011). Effect of salinity on growth, xylem structure and anatomical characteristic of soy bean. Not Sci Biol 3 (pp. 41-45) Academic Press.

Doyle, J.J., \& Doyle, J.L. (1990). Isolation of plant DNA from fresh tissue. Focus Journal 12 (13-15).

El-Rodeny, W.M., \& El-Okkiah, A.F.S. (2012). Physiological and anatomical changes in Glycine max L. Under salinity stress. Egypt. Journal Botany (pp. 37-50). Agricultural Botany Departement, El-Sheikh University, Egypt.

Esau, K. (1985). Plant anatomy. Third-ed. Wiley Eastern Limited, New Delhi 110 002.

Fahn. (1991). Plant Anatomy. Third Ed. Pergamon Press. Ltd. Oxford

Hadrys, H., Balick, M., \& shearwater, B. (1992). Application of random amplified polymorphic DNA (RAPD) 
in molecular ecology. Molecular Ecology Journal 1(pp. 55-63).

Hussien, M.D., Habeballa, R, S., Elhadi, E.A., and Khalafalla, M.M. (2011). Random Amplified Polymorphic DNA (RAPD) marker associated with salt tolerance during seeds germination and growth of selected Acacia senegal provenances. African Journal of Biotechnology. Vol. 10 (31) : $5820-5830$.

Kazem, G.G., and Minoo, T. 2011. Soy bean performance under salt stress. www.intchopen.com : $631-642$.

Khalid, N., Khalid, H., Abdul, M., Farah, K., Shahid, K., \& Kazim, A. (2010). Fatality of salt stress to plants: morphological, physiological and biochemical aspects. 9 (pp. 5475-5480). African Journal of Biotechnology. http://www.academicjournal.org/AJB.

Kondetti, P., Jawali, K.N., Afte, S.K., and Shitole, M.G. (2012). Salt Tolerance in Indian Soy bean (Glycine max (L.) Merrill. Annals of Biological Research Library. Coden (USA). 3: 1489 - 1498.

Makbul, S., Guler, N.S., Durmus, N., \& Guven, S. 2011. Change in anatomical and physiological parameters of soybean under drought stress. Turk Journal Botany 35: 369- 377.

Murat, T., Ruveyde, T., Yidirin B., and Vehdetin C. 2011. Effect of salinity stress on plant fresh weight and nutrient composition of some canola (Brassica napus L.) cultivar. African Journal of Biotechnology. Vol. 10 (10).

Mansoor, H., Ashraf, M., Nargis, N., Tahira, N., Riffat, B., Aqeel, M.S.A., Farooq, A., \& Mumtaz, H. (2013). Anatomical adaptation of Cynodon dactylon (L.) Pers from the salt range to salinity stress. Fak. Journal Botany 45 (pp. 132142). Departement of Botany, University of Agricultural, Faisalabad, Pakistan.
Sass, J.E. (1958). Botanical Microtechnique. Third edition. The Iowa State College Press Iowa.

Sopalian, O., Miandoab, P.B., Asghari, A., Sedghi, M., \& Eshghi, A. (2013). The Relationship between salt tolerance related Physiological Traits and protein markers in soybean cultivar (Glycine $\max$ L.). Cercetari Agronomic in Moldova. (pp. 47-56).

Sukmarani, D. (2013). Genetic variation Cerioptagal mangrove species based on RAPD marker. Biosfera, A scientific Journal, Biology Faculty, General Soedirman University. 30 (pp. 99-107).

Suryanto, D. (2002). Biodiversity organism observation with genetic molecular techniques. USU. Medan. Indonesia.

Triyani, A., Suwarto \& Siti, N. (2013). Soy bean genitive tolerance (Glycine max (L.) Merrill) on salinity concentration at vegetative phase. Agronomic 13 (pp. 19).

Yuniati, R. (2004). Soy bean (Glycine max (L.) Merrill) genotype screening on $\mathrm{NaCl}$ for planting at a saline area. Makara Sains Vol 8 (1): (pp. 21-24). FMIPA, Indonesia University, Depok, Indonesia.

Zahra, R., and Mehdi, A.S.K., 2011. The effect of salinity and seed size on seed reserve utilization and seedling growth of soy bean (Glycine max). International Journal of Agronomy and Plant Production. Vol. 2 (1) : $1-4$. Victor Quest Publications. 